\title{
THE EFFECT OF FIRM COMPENSATION STRUCTURES ON EMPLOYEE MOBILITY AND EMPLOYEE ENTREPRENEURSHIP OF EXTREME EMPLOYERS
}

\author{
by \\ Seth Carnahan * \\ University of Illinois \\ Rajshree Agarwal * \\ University of Illinois \\ Benjamin Campbell * \\ Ohio State University \\ and \\ April Franco * \\ University of Toronto
}

CES 10-06

March, 2010

The research program of the Center for Economic Studies (CES) produces a wide range of economic analyses to improve the statistical programs of the U.S. Census Bureau. Many of these analyses take the form of CES research papers. The papers have not undergone the review accorded Census Bureau publications and no endorsement should be inferred. Any opinions and conclusions expressed herein are those of the author(s) and do not necessarily represent the views of the U.S. Census Bureau. All results have been reviewed to ensure that no confidential information is disclosed. Republication in whole or part must be cleared with the authors.

To obtain information about the series, see www.ces.census.gov or contact Cheryl Grim, Editor, Discussion Papers, U.S. Census Bureau, Center for Economic Studies 2K130B, 4600 Silver Hill Road, Washington, DC 20233, CES.Papers.List@census.gov. 


\begin{abstract}
Previous studies of employee entrepreneurship have not considered the rewards available to potential entrepreneurs inside of their current organizations. This study hopes to fill this gap by investigating how the firm's compensation structure, an important strategic decision closely scrutinized by human resource management, affects the mobility and entrepreneurship decisions of its employees, particularly those employees at the extreme ends of the performance distribution. Using a comprehensive U.S. Census data set covering all employees in the legal services industry across ten states for fifteen years, we find that high performing employees are less likely to leave firms with highly dispersed compensation structures. However, if high performers do leave employers that offer highly disperse compensation structures, they are more likely to join new firms. Less talented employees, on the other hand, are more likely to leave firms with greater pay dispersion. Unlike high performers, we find that low performers are less likely to move to new ventures when departing firms with highly disperse compensation structures.

* This research uses data from the Census Bureau's Longitudinal Employer Household Dynamics Program, which was partially supported by the following National Science Foundation Grants SES-9978093, SES-0339191 and ITR-0427889; National Institute on Aging Grant AG018854; and grants from the Alfred P. Sloan Foundation. Any opinions and conclusions expressed herein are those of the authors and do not necessarily represent the views of the U.S. Census Bureau. All results have been reviewed to ensure that no confidential information is disclosed.
\end{abstract}




\begin{abstract}
Previous studies of employee entrepreneurship have not considered the rewards available to potential entrepreneurs inside of their current organizations. This study hopes to fill this gap by investigating how the firm's compensation structure, an important strategic decision closely scrutinized by human resource management, affects the mobility and entrepreneurship decisions of its employees, particularly those employees at the extreme ends of the performance distribution. Using a comprehensive U.S. Census data set covering all employees in the legal services industry across ten states for fifteen years, we find that high performing employees are less likely to leave firms with highly dispersed compensation structures. However, if high performers do leave employers that offer highly disperse compensation structures, they are more likely to join new firms. Less talented employees, on the other hand, are more likely to leave firms with greater pay dispersion. Unlike high performers, we find that low performers are less likely to move to new ventures when departing firms with highly disperse compensation structures.

* This research uses data from the Census Bureau's Longitudinal Employer Household Dynamics Program, which was partially supported by the following National Science Foundation Grants SES-9978093, SES-0339191 and ITR-0427889; National Institute on Aging Grant AG018854; and grants from the Alfred P. Sloan Foundation. Any opinions and conclusions expressed herein are those of the authors and do not necessarily represent the views of the U.S. Census Bureau. All results have been reviewed to ensure that no confidential information is disclosed.
\end{abstract}


Scholars examining employee entrepreneurship have established that individuals who leave current employers to create competing organizations (defined as spin-out firms) are typically high performers (Campbell, Ganco, Franco and Agarwal, 2010; Groysberg, Nanda and Prats, 2009; Elfenbein, Hamilton and Zenger, 2009). Armed with superior human capital (Bragusinksy and Ohyama, 2009) and social capital (Stuart and Sorenson, 2001) that helps attract financial resources (Shane and Cable, 2002) and other complementary assets (Teece, 1986), high performing individuals are favorably positioned to succeed in their new venture undertaking (Agarwal, Campbell, Franco and Ganco, 2010). A related stream of literature has examined parent firm characteristics as antecedents to spin-out generation and success, highlighting the role of parent size (Elfenbein, et al., 2009; Parker 2009), entrepreneurial incentives (Anton and Yao, 1995), learning through apprenticeships (Franco and Filson (2006); Gompers, Lerner and Scharfstein, 2005,) organizational culture (Burton, Sorenson and Beckman, 2002), and underexploited knowledge (Agarwal, Echambadi, Franco and Sarkar, 2004; Klepper and Thompson, 2010) in determining the rate of spin-out generation and their subsequent success. Since employees decide whether or not to engage in entrepreneurship when embedded in the parent's organizational structure, an important unaddressed research gap in the talent-entrepreneurship relationship relates to the contingency role of the structural characteristics of the parent firm.

In this study, we seek to address this gap by examining how a firm's compensation structure, a crucial strategic decision studied by human resource management scholars (Shaw and Gupta, 2007; Bloom and Michel, 2002; Shaw, Gupta and Delery, 2002; Bloom, 1999; Gerhardt and Rynes, 2003), influences the mobility and entrepreneurship decisions of employees that vary in talent and individual performance. In doing so, we link heterogeneity among individual performance to the heterogeneity among firm compensation structures in rewarding individual performance and examine how they interact to influence the employee mobility or entrepreneurship decision. Given our dual focus on both individual and firm level characteristics, we draw upon related work in labor economics, human resource management, and strategy to develop our hypotheses. We test our 
hypotheses using unique and comprehensive data from a custom extract of the Longitudinal Employer Household Dynamics project (LEHD) created by the US. Census Bureau.

Our study hypothesizes and shows that relative to average performers, high performing individuals are less likely to leave parent firms that provide more dispersed wage structures and thus greater opportunities to earn extreme rewards. However, when high performers choose to leave organizations with more dispersed wage structures, they are more likely to form their own firms. In contrast, we hypothesize and show that low performing employees are more likely to leave firms that offer extreme rewards than firms with less wage dispersion. Further, when low performers leave firms that emphasize extreme rewards, they are less likely to form their own firms. For low performers at firms that offer extreme rewards, alternative employment options at established firm may not link pay as tightly to performance and additionally, low performers more likely have a relative lack of capabilities to engage in successful entrepreneurship which makes mobility to established firms more desirable than mobility to new firms.

In undertaking this study that examines both micro and macro level determinants of employee mobility and entrepreneurship, we hope to make contributions to multiple literature streams that examine issues related to strategic human capital. Within strategic management of knowledge, the study contributes to the literature by linking the firm's compensation structure, an important macro-level strategic decision, to the micro-level mobility and entrepreneurship behavior of employees. Previous studies linking firm-level contingencies to individual decisions have mainly focused on how the firm's configuration of technical and knowledge assets (Agarwal, et al, 2004; Franco and Filson, 2006) and its environment (Gompers, Lerner and Scharfstein, 2005; Klepper and Thompson, 2010) determine the likelihood of its employees starting new ventures, without examining how such firm level characteristics may influence heterogeneous employees differently. Not only do we provide the complementary insight that the firm's compensation structure also matters, we also highlight the differential effect of firm compensation structures on employees that vary in their performance. Talented employees may exit established firms to join new ventures in order to seize on underexploited opportunities (Agarwal, et al, 2004; Klepper and Thompson, 2010), 
but they will also seek out the organizational structure that allows them to maximize the returns to their ability.

Similarly, we contribute to the human resource management literature on turnover by highlighting that not all mobility events are the same and that destination matters in employee mobility. While firm policies that reward extreme performance do help in retaining high-performing employees, these compensation structures may nonetheless be less effective in curtailing employee entrepreneurship over employee mobility. Compensation structures that are less closely tied to extreme performance may retain low and average performers disproportionately more than high performers, who prefer the more lucrative pastures of entrepreneurial venturing or firms that are willing to compensate them at greater levels.

Finally, we contribute to the entrepreneurship literature by systematically comparing the decision to join an entrepreneurial venture to the entire set of options that individuals have, including staying at the existing organization or moving to an alternative established firms. Importantly, we highlight the interaction of heterogeneity of individual performance with heterogeneity in compensation structures among existing firms as employees contemplate the decision to venture on their own. In doing so, we advance the literature by integrating research in employee entrepreneurship with research on employee mobility, and by providing a more holistic view of how both individual and firm level characteristics affect the employee's exit decision in tandem, rather than in isolation of each other.

\section{THEORY AND HYPOTHESES}

\section{Heterogeneity in Individual Performance}

Industries are composed of heterogeneous individuals who, due to differences both observable (e.g. education) and unobservable (e.g. motivation), achieve differing levels of individual performance. Researchers have argued that firms deal with this heterogeneity by gearing their management of strategic human capital to identify and then retain or discard extreme performers, whose demonstrated skills are either remarkably higher or remarkably lower than referent individuals (Zenger, 1992). Firms work to identify and retain high performers because these individuals not only drive firm success (Audretsch and Stephen, 1996; Zucker, Darby and Armstrong, 2002; Ernst 
and Vitt, 2000; Mindurta, 2008) but they are also able to leave the firm and use their talents to create new ventures that compete directly with their former employers (Groysberg, et al. 2009; Campbell, et al. 2010). On the other hand, the contributions of low performers can be a drag on firm profitability (Krackhardt and Porter, 1981; Williams and Livingstone, 1994).

Previous studies of extreme performers have identified these individuals by comparing their performance to different reference groups. Studies of human resource practices have defined extreme performers by comparing employees to their coworkers at the firm level of analysis (e.g. Zenger, 1992; Shaw and Gupta, 2007; Pfeffer and Davis-Blake, 1992) while studies of industry evolution have defined extreme performers by comparing workers at the industry level of analysis (e.g. Aduretsch and Stephen, 1996; Zucker, Darby and Brewer, 1998). Because this study examines individual heterogeneity in the context of mobility outside the boundaries of the firm, we also adopt the industry level of analysis and identify extreme performers by comparing the performance of workers to other similar employees in the same metropolitan statistical area.

The firm's compensation structure is a key tool in the firm's quest to attract, identify, and either retain or discard extreme performers. We consider this important strategic decision in the following section.

\section{Compensation Structures and Value Appropriation by Heterogeneous Employees}

When designing compensation policies, a firm must consider both pay levels and pay structures (Gerhart and Rynes, 2003). Pay level dictates how much employees will be paid for performing different jobs (Gerhart and Rynes, 2003) while pay structure determines the potential variance in pay among different employees in the organization. When this variance stems from differences in pay level across hierarchical levels of the organization, it is referred to as vertical pay dispersion. Alternatively, when the variance occurs within the same job group or level, dictated by factors such as performance or seniority heterogeneity among employees (Powell, Montgomery and Cosgrove, 1994) it is referred to as horizontal pay dispersion (Shaw and Gupta, 2007).

When firms implement differential rewards using either or both types of pay dispersion (Gerhart and Rynes, 2003), the compensation structure exhibits higher variance, and more of the firm's wages are concentrated in the hands of fewer individuals. As a result, the firm's choice of compensation structure also has an impact on its employees' ability to appropriate the value 
generated by the firm (Coff, 1999). A firm that implements a high variance compensation structure is willing to provide extreme rewards to the employees that are perceived to create more value (Blyler and Coff, 2003). Doing so should increase satisfaction levels of high performing employees, whose superior ability is recognized and rewarded through either horizontal or vertical pay dispersion because high performers can earn greater within-job-group performance-based rewards or climb the job ladder more quickly (Bloom and Michel, 2002; Campbell et al, 2010). Given higher wages than their comparison group within the firm (Pfeffer and Davis-Blake, 1992), such high performers appropriate more of the value created within the firm. Lower performing employees, on the other hand, appropriate less of the value generated by the firm.

The situation is different in organizations with more egalitarian compensation structures. In such settings of low variance in compensation, low and high performers are likely to earn similar wages for different levels of performance. This lack of differentiation may limit jealousy (Lazear, 1989) and costly comparison behavior (Nickerson and Zenger, 2008) and engender cooperation (Frank, 1984; Shaw, Gupta and Delery, 2002) but it may also result in an implicit cross-subsidization of low performing individuals by high performing individuals, since the compensation schemes are not directly tied to individual performance. Lower variance in compensation structures thus may decrease satisfaction levels of high-performing employees but increase it for the lower performing individuals.

Differences in compensation structures will accordingly result in different effects on employees that vary in their individual performance, particularly as they contemplate their employment options outside the firm boundaries. We examine this relationship in the following section.

\section{Compensation Structures and Mobility of Extreme Performers}

A firm's compensation structure dictates the ability of its employees to earn value commensurate with their talent within the boundaries of the firm, and accordingly has a strong influence on the exit behavior of the firm's employees (Lazear and Rosen, 1979; Pfeffer and Davis- 
Blake, 1992; Lazear, 1999; Bloom and Michel, 2002; Shaw and Gupta, 2007). A firm whose compensation structure exhibits more dispersion (whether vertical or horizontal) and provides for extreme rewards permits higher performing individuals to appropriate a large part of the value created by the firm (Coff, 1997; Weiss, 1990), and earn wages that correspond to the value of their talents $^{2}$ (Zenger, 1992).

The presence of extreme rewards should discourage the mobility of high performers, since they can earn rents that are equal to or higher than what is needed to prevent them from quitting the firm (Milgrom and Roberts, 1992). Vertical pay dispersion reduces mobility of employees who have higher levels of education, experience and expertise and thus ascend to more senior positions in the firm by providing pecuniary compensation that is more aligned to the different levels of responsibility and standing that come with ascending the organizational hierarchy (Bloom and Michel, 2002). Similarly, horizontal pay dispersion reduces mobility since high performing employees perceive themselves to be well-compensated (Parsons, 1977; Powell, Montgomery and Cosgrove 1994), particularly in comparison to their lower performing coworkers at their current employer (Pfeffer and Davis-Blake, 1992; Shaw and Gupta, 2007). Even if these high performing individuals are rising stars who have not yet reached the highest absolute pay levels, their higher compensation relative to peers in their job group (Shaw and Gupta, 2007) will provide positive social comparisons and decrease their probability of exit (Berkowitz, Fraser, Treasure and Cochran, 1987; Festinger, 1954). In sum, a dispersed compensation structure should allow high performing employees to appropriate more value, allowing them to earn rents, or wages in excess of what would be needed to prevent them from quitting the firm (Milgrom and Roberts, 1992; Coff, 1999), leading to the following hypothesis:

Hypothesis 1: High performers will be less likely to exit as the dispersion of their employer's wage distribution increases.

\footnotetext{
${ }^{2}$ It is important to note that because we are discussing high and low performing employees in the context of interfirm mobility and new firm creation, we define high and low performers not by their position in the firm level performance or pay distribution (as in Shaw and Gupta, 2007; and Pfeffer and Davis-Blake, 1992 respectively) but rather by their position in the performance distribution within the metropolitan statistical area. As a result, it is possible that some firms may not employ any high performers or low performers.
} 
The opposite will likely be true for low performers. If the firm implements a vertically dispersed compensation structure, low performers are unlikely to meet the rigorous standards necessary to ascend the organizational hierarchy (Bloom and Michel, 2002). Because individuals may value the increases in recognition (Stumpf and Dawley, 1981) and responsibility (Dwyer and Ganster, 1991) that usually accompany a promotion, a reduction in both actual promotions and the individual's perception of his likelihood of being promoted will reduce the job satisfaction of low performers in firms with vertically dispersed compensation structures (Marsh and Mannari, 1977). In a horizontally dispersed compensation structure, the low performer will be unable to achieve the same performance based rewards as their most proximate peers in the firm (Shaw and Gupta, 2007).

These individuals may attribute their inability to ascend the organizational hierarchy or earn performance-based rewards to factors other than their own effort (Lewicki, 1983), such as poor fit with the organization, either culturally (Chatman, 1989) or from a job design perspective (Holmstrom and Milgrom, 1991). As a result, equity theory (Adams, 1963) suggests that low performers in firms with more dispersed compensation structures may begin to envy their coworkers (Nickerson and Zenger, 2008; Salovey, 1991) and suffer negative social comparison costs as a result (Festinger, 1954). These negative social comparisons will likely lead to lower job satisfaction (Berkowitz, Fraser, Treasure and Cochran, 1987), a key predictor of employee's intention to exit their jobs (see Griffeth, Hom and Gaertner, 2000, for a recent meta-analytic review).

In order to alleviate negative comparisons and increase job satisfaction, low performers may prefer to leave in search of an employer that does not link promotions and pay so tightly to relative performance (Miyazaki, 1975; Pfeffer and Davis-Blake, 1992). As a result of these arguments, we have the following hypothesis:

Hypothesis 2: Low performers will be more likely to exit as the dispersion of their employer's wage distribution increases. 


\section{Compensation Structures and New Venture Creation by Extreme Performers}

Having examined the mobility behavior of extreme performers based on variation in compensation structures, we next focus on the question of where these individuals are likely to go upon exit from former firms. Specifically, we examine the incidence of new venture creation versus mobility to established competitors, given both individual level heterogeneity in performance and firm level heterogeneity in compensation structures.

Extant literature on employee entrepreneurship provides valuable insights regarding either the effect of firm level characteristics or individual attributes but has not considered the two factors in tandem. In the context of parent firm characteristics, scholars have examined how a firm's performance (Klepper and Sleeper, 2005), size (Parker, 2009; Elfenbein, et al, 2009) and configuration of technical and knowledge assets (Agarwal, et al, 2004; Franco and Filson, 2006) affect the likelihood of its employees to start new ventures. Findings generally indicate that smaller firms (Boden, 1996; Sørenson, 2007) and firms with underexploited knowledge (Agarwal, et al. 2004) or an entrepreneurial culture (Gompers, Lerner and Scharfstein, 2005; Burton, Sørenson and Beckman, 2002) produce more spin-outs. Left unanswered in this literature stream, however, given that individuals are embedded in their employing firm, is how differences in compensation structure at their employer impact the choice of employee entrepreneurship. In the context of individual characteristics, scholars have noted that high performing individuals are more likely to engage in entrepreneurial venturing than moving to established firms (Campbell, et al 2010; Elfenbein, et al. 2009; Groysberg, et al, 2009). Primarily, they attribute these differences to the maximization of performance-contingent rewards for the entrepreneurial founder (Bragusinksy and Ohyama, 2009) and to the ability of high performing employees to more successfully transfer the complementary assets necessary to start a new venture (Campbell, et al 2010). An unanswered question in this literature stream relates to the contingency role of compensation structures at the parent firm on the decision to engage in entrepreneurial activity by employees who differ in their performance.

The firm's compensation structure, we posit, will interact with the heterogeneity in individual performance to determine whether extreme performers who leave their current organizations 
choose to join established competitors or start new firms of their own. High performers that decide to depart organizations that already provide access to extreme rewards may have fewer options among established competitors if they want to increase their ability to appropriate the value created by the firm. An entrepreneurial venture may be attractive to these employees because founders of the firm are residual claimants who can appropriate maximum performance-based rewards, similar to working entirely on commission (Harrison, Virick and William, 1996). In addition, there appears to be little reason for a high performer to move to a different established firm if his current firm already provides extreme rewards. Moving to an established competitor will require the high performer to adapt to the routines of that firm (Ganco, 2009) and develop new firm-specific investment in human capital (Becker, 1962), each of which may reduce the productivity of the high performer, at least in the short term. Such sacrifices might be worthwhile if the established competitor provides the high performer with greater compensation. However, if the high performer's current organization already provides access to extreme rewards, the high performer will have weaker pecuniary incentives to switch firms. A new venture, on the other hand, allows the high performer to transfer the routines (Wezel, Cattani and Pennings, 2006) and complementary assets (Campbell, et al., 2010) of the parent organization as well as maximize the high performer's ability to earn performance contingent rewards (Bragusinksy and Ohyama, 2009).

Additionally, nonpecuniary aspirations may influence the high performer's decision to start her own firm. High performers at firms that offer extreme rewards are likely to be high earners and thus may face diminishing marginal returns to pecuniary gain and consequently place a greater relative value on nonpecuniary factors such as job satisfaction and autonomy than high performers at firms that do not provide extreme rewards (Blanchflower \& Oswald, 1998; Gompers et al., 2005; Hamilton, 2000; Puri \& Robinson, 2006; Teece, 2003). Thus, starting a new venture might be the only option for a high performing employee who decides that her current firm, although it provides high access to extreme rewards relative to competitors, still does not give her a return (both pecuniary and nonpecuniary) commensurate with her ability. 
Hypothesis 3: Conditional on mobility, the probability that high performers will form a new venture is positively related to the wage dispersion of their former firm at time of exit.

As a contrast to high performers, we next consider the entrepreneurial behavior of low performing employees who decide to change firms. As mentioned earlier, a low performer in a firm with greater pay dispersion may be envious of their colleagues and suffer negative social comparisons (Lambert, Larcker and Weigelt, 1993). However, starting a new venture is not likely to be the value-maximizing decision for these individuals. A low performer likely does not have the human capital (Bragusinksy and Ohyama, 2009) and social capital (Stuart and Sorenson, 2001) necessary to attract financial resources (Shane and Cable, 2002), as well as other complementary assets necessary to form a successful new venture (Agarwal et al, 2010; Campbell et al, 2010). The same characteristics that prevent the low performer from succeeding in a firm with an emphasis on extreme rewards will also decrease his chances of succeeding in entrepreneurship.

As a result, a low performer leaving a firm with a greater emphasis on extreme rewards may be able to improve his situation more by joining a different established competitor than by forming a startup. To the extent that the low performer was located in the lower tail of his previous employer's pay distribution, joining a firm with a more equitable wage structure will alleviate some of the negative social comparison effects felt by low performers in dispersed firms (Pfeffer and Davis-Blake, 1992). In sum, as the wage dispersion of his current employer increases, there will likely be more attractive options among established firms for low performing employees who exit and are unlikely to possess the human capital necessary to attract enough complementary assets to start a new venture.

Hypothesis 4: Conditional on mobility, the probability that low performers will form a new venture is negatively related to the wage dispersion of their former firm at time of exit.

\section{DATA AND METHODS}

\section{Empirical setting}

We tested our hypotheses in the US legal services industry. This industry is an appropriate setting for several key reasons. First, it is representative of professional services, which is a large and 
growing portion of the US economy, constituting $46.5 \%$ of the US GDP in $2007^{3}$. In spite of the importance of professional services to economic output, and the importance of employees as conduits of knowledge diffusion and transfer in this sector, there are disproportionately few studies that use professional services as an empirical context, a gap that we address in this study. Second, the structure of the industry facilitates studies of employee mobility and new firm generation. Specifically, professional services industries are human capital intensive, where critical complementary assets are more likely to be embodied in people than physical plants or firm owned intellectual property (Teece, 2003) and employment contracts in legal services exclude noncompete clauses and, for lawyers who have passed relevant bar exams, the barriers to mobility and entry are low. As a result, the costs associated with mobility (within the borders of a state) are relatively low for employees and new firm creation rates are high ${ }^{4}$. Thus, the legal services industry represents an active environment in which to study moves to both established firms and spin-outs (Campbell, et al. 2010).

Finally (and most importantly), the heterogeneity in compensation structures utilized by legal services firms facilitates the study of firm structures on employee mobility. In addition to the vertical and horizontal pay dispersion observed in other industries, legal services firms also vary in their personnel hiring/retention strategies (Malos and Campion, 1995; Parkin and Baker, 2006). One common personnel strategy is the well-known tournament model, where a firm employs many associates and a few highly-paid partners. These firms pay their associates lower salaries based on the prospects of future partnership (Malos and Campion, 1995) and rely on an "up-or-out" model whereby associates who do not make partner generally leave the firm (Parkin and Baker, 2006). In another common personnel strategy, firms choose to look both inside and outside a firm when recruiting partners. Since partners may be heavily recruited from outside firm boundaries, this model gives internal associates fewer opportunities to make partner (Malos and Campion, 1995).

\footnotetext{
${ }^{3}$ Statistics on GDP by industry are from the Industry Economic Accounts Program at the Bureau of Economic Analysis. Data are available at http://www.bea.gov/industry/xls/GDPbyInd_VA_NAICS_1998-2008.xls.

${ }^{4}$ Lawyers' credentials are state-specific and are easily transferrable within state borders, but not easily transferrable across state borders which implies that mobility costs are low within states and high between states.
} 
As a result, associates' salaries are generally higher because the firm does not necessarily offer the prospect of future partnership. Because these firms do not rely heavily on the up-or-out model, associate turnover levels are generally lower.

In summary, the legal services industry is an ideal context for our study. The industry has rich variation in individual performance and firm compensation structures, and high incidence of employee mobility and entrepreneurship. In addition, by applying our hypotheses to the legal services industry, our study will provide insights on the effect of a critical strategic decision (the legal services firm's compensation structure) on the mobility of workers in an economically important industry.

\section{Data source}

In this study, we analyze data from the Longitudinal Employer-Household Dynamics (LEHD) Project. The LEHD project constructs linked employer-employee data from state-level unemployment insurance (UI) records and other data products from the U.S. Census Bureau. ${ }^{5}$ The data contain quarterly records of all employee-employer dyads covered by the UI system. For each dyad we observe employee earnings for the quarter, employee characteristics, and employer characteristics. Our extract of the data includes all individuals who worked in the legal services industry in any of ten large states between 1990 and 2004. The data are administrative and universal which facilitates tracking employee mobility and identification of start-ups and spin-outs in the data.

We restrict the data to include individuals who have strong ties to the labor market and firms that are large enough to have a meaningful measure of compensation structure. Specifically, we limit the sample to individuals making at least $\$ 25,000$ in a given year and firms which contain more than five people making at least $\$ 25,000$. Additionally, we restrict the data to firms that survive for at least two more years from the focal year. This last restriction allows us to focus on employee mobility from healthy firms because employees that leave dying firms are making a fundamentally different decision than employees that leave healthy firms.

\footnotetext{
${ }^{5}$ For more information on the LEHD program, see http://lehd.did.census.gov/led/library/tech_user_guides/overview_master_zero_obs_103008.pdf
} 


\section{Estimation strategy}

In our estimation, our unit of observation is the employee-year. For each employee-year we estimate a series of linear probability models with dependent variables that indicate exit and exit to a new venture. Inclusion of firm-year fixed effects absorbs any variation attributable to unobserved characteristics that are constant within firm-years. While a conditional logit model may potentially be a better match for our hypothesized relationships than a linear probability model, computing constraints restricted our choice of model. To ensure confidentiality of the data, all analyses had to be performed on-site at a Census Research Data Center using their computing resources. Limits on the time and computing power available to us restricted our choice of empirical methodologies and precluded estimation of conditional logit models on all but a small subset of the data. However, to compare the results of linear probability model to the results of a conditional logit model, we estimated conditional logit specifications on a random subsample of our data and our results were not materially different from those presented below. In the linear probability estimates, we included robust standard errors (clustered by firm year) to account for heteroskedasticity inherent in the specification. In our data, out-of-sample predictions were very rare, which provided evidence that our linear probability model was performing acceptably.

\section{Variables}

Employee mobility. In the tests of Hypotheses 1 and 2 the dependent variable is employee mobility, which takes the value of one if an employee's dominant employer changed since the previous year and zero otherwise. Because some individuals work at multiple firms within a given year, we focus on an individual's dominant employer which is the firm at which the employee earned the most during the year.

Our data do not permit the identification of voluntary or involuntary mobility. We expect that due to their exceptional abilities, on average, high performers will not be involuntarily terminated from their jobs. We are agnostic as to whether low performers experience voluntary or involuntary mobility. However, since one of the objects of a dispersed wage distribution is to allow incentives to sort high-skilled and low-skilled employees with less managerial intervention (Lazear 
and Rosen, 1979; Rasmussen and Zenger, 1990), low performers should be spurred to seek different employment options when they do not obtain the performance-based incentives or promotions necessary to earn rents in a dispersed wage distribution. Thus, involuntary mobility of low performers should occur more often in firms with more equitable wage distributions. As a result, the presence of involuntary mobility in our data will bias results away from the confirmation of our hypotheses and provide conservative tests.

Employee exit to spin-out. In the tests of Hypotheses 3 and 4 the dependent variable is a dummy variable that takes the value of one if an employee's dominant employer changed since the previous year and the subsequent employer is a new firm in the data. We note that this measure of exit to spin-out includes not just firm founders but also early stage, nonfounding employees. Hypotheses 3 and 4 are in line with this distinction and focus not on the founding of new firms, but on exiting an established firm to join a new firm.

Firm's wage dispersion. We follow other studies of compensation dispersion (Bloom, 1999; Bloom and Michel, 2002; Shaw, Gupta and Delery, 2002) and use the firm's Gini coefficient to measure the firm's compensation structure. The Gini coefficient is a commonly used measure of income inequality in labor economics (Bloom, 1999; Donaldson and Waymark, 1980). The Gini coefficient, which ranges between 0 and 1 , measures half the relative mean difference of the wages of any two employees selected at random from the firm's wage distribution. A Gini of one indicates absolute inequality, where one person in the firm earns 100\% of the wages, while a Gini of zero indicates absolute equality, where everyone in the firm makes the exact same wage. Specifically, the Gini can be calculated as

$$
G=\frac{2 \sum_{i=1}^{n} i y_{i}}{n \sum_{i=1}^{n} y_{i}}-\frac{n+1}{n}
$$

where $y_{\mathrm{i}}$ is the salary of the $\mathrm{i}$-th ranked individual in the firm and is indexed in nondecreasing order, i.e. $\mathrm{i}=1$ indicates the lowest paid person in the firm and $\mathrm{n}$ is the number of people in the firm. 
High and low performing employees. As in prior studies (Elfenbein, et al, 2009), we rely on objective wage data to identify high and low performers. Since it is important to isolate individual level performance from firm level compensation structures, we define high and low performance employees relative to a reference set of all legal services employees in the same metropolitan statistical area ${ }^{6}$.

Elfenbein et. al (2009) account for individual characteristics such as educational levels, and then define high and low performers as individuals in the top $10 \%$ and bottom $10 \%$ of the wage distribution. Extending their framework to our context, we employ a wage residual approach in identifying extreme performers. This is important because it permits us to control for pay differences associated with experience (age) when identifying extreme performers. For example, using a raw wage distribution rather than the wage residual distribution may cause some young, lowpaid individuals to be identified as low performers when in fact they might be high performers among their cohort.

We develop our measure for extreme performers using a two step procedure. First, we estimate the following wage equation by OLS for each person-year in our untrimmed sample:

$$
\begin{aligned}
& \log w_{i t}=\beta_{0}+\beta_{1} a g e_{i t}+\beta_{2} a g e_{i t}{ }^{2}+\beta_{3} \text { white }_{i}+\beta_{4} e d u c_{i}+\beta_{5} e d u c_{i}{ }^{2}+\beta_{6} \text { tenure }_{i j j}+\beta_{7} \text { tenure }_{i j}{ }^{2}+\beta_{8} \text { tenure_cen }_{i j} \\
& +\beta_{9} i n \_m s a_{i t}+\beta_{10} \text { in_msa }^{*} \text { density_msa } a_{i t}+\beta_{11} \text { density_state }_{i t}+\beta_{12} M S A+\beta_{13} S T A T E+\beta_{14} Y E A R+u_{i t}
\end{aligned}
$$

where $\mathrm{w}_{\mathrm{it}}$ is person $i$ 's total taxable compensation in year $t$ (including salary, bonuses and other reported taxable income), age ${ }_{\mathrm{it}}$ is the age of person $i$ at time $t$, white ${ }_{\mathrm{i}}$ is a dummy which take the value of one if the person is white, educ is a time-invariant measure imputed by the Census which indicates the number of years of the individual's schooling, tenure ${ }_{\mathrm{itj}}$ is the number of years person $i$ has spent with firm $j$ as of time $t$, tenure_cen ${ }_{\mathrm{itj}}$ is a dummy which takes the value of one if person $i$ 's tenure with firm $j$ is left-censored (this control is important because our data begin in the middle of

\footnotetext{
${ }^{6}$ Results do not change if we identify the cohort at the state level of analysis, and we note here that given high barriers to across state mobility, reference sets beyond state levels can be misleading and confound variations due to state level differences in legal services industry characteristics. Because previous work indicates that employer search for new hires may be geographically constrained (Rees, 1966) particularly for lawyers (Parkin 2006) and that employees are less likely to move great distances for new jobs (Lee and Mitchell, 2001), we focus on the MSA-level reference set in our reported results.
} 
the careers of some employees), in_msa ${ }_{\mathrm{it}}$ is a dummy variable which equals one if person $i$ works in a Metropolitan Statistical Area (MSA) in time $t$, in_msa*density_msa ${ }_{\mathrm{it}}$ is an interaction term between the in_msa $\mathrm{it}_{\mathrm{it}}$ variable and the number of legal services firms active in person $i$ 's MSA at time $t$, density_state ${ }_{\mathrm{it}}$ is the number of legal service firms active in individual $\imath$ 's state at time $t$, MSA, STATE and YEAR are vectors of dummy variables for the more than 150 MSA's, 10 states, and 15 years in our sample; and $\mathrm{u}_{\mathrm{it}}$ is the error term.

In the second step, we use the residual $\mathrm{u}_{\mathrm{it}}$ distribution from the estimated equation to identify high and low performers as those individuals within the top $10 \%$ and bottom $10 \%$, respectively, of that individual's Metropolitan Statistical Area. Doing so permits us to identify individuals who earn in the top $10 \%$ and bottom $10 \%$ of the wage distribution of people with the same observable characteristics. We then create two dummy variables. The first takes a value of one if individual $i$ is identified as a high performer at time $t$. The second takes a value of one if individual $i$ is identified as a low performer at time $t$.

For individuals located outside of MSA's, we created high and low performer cutoffs that are the weighted average of high and low performer cutoffs for all the MSA's in that person's state. For example, consider a lawyer working in rural Nebraska. ${ }^{7}$ There are three MSA's in Nebraska: Lincoln, Sioux City, and Omaha. Assume that the minimum $\mathrm{u}_{\mathrm{it}}$ required to be considered a high performer in year $t$ is 2 in Lincoln, 4 in Sioux City, and 5 in Omaha and that there are 5,000 legal services employees in Lincoln, 2,000 in Sioux City, and 10,000 in Omaha. A lawyer working in rural Nebraska would be considered a star in year $t$ if his $\mathrm{u}_{\mathrm{it}}$ is greater than $3.99=2 *(5,000 / 17,000)+$ $4 *(2,000 / 17,000)+5 *(10,000 / 17,000)^{8}$.

Defining high and low performers based on their wage residual has two primary advantages. First, since the variable effectively measures lawyers' earnings against the average of other lawyers in their demographical and geographical cohort, we are able to identify lawyers who may not have

\footnotetext{
${ }^{7}$ Nebraska is not necessarily in our sample.

${ }^{8}$ Because legal services firms and lawyers in rural areas may differ systematically from those in urban areas, we also computed models where we considered all rural lawyers in a given state to be a unique reference set (i.e. we treated the rural part of each state to be its own MSA) and identified rural extreme performers based on this statewide rural wage residual distribution. Our results are robust to this alternative specification.
} 
extremely high or extremely low absolute earnings but nonetheless have earnings that are at the extremes of their cohort. Second, by defining extreme performers based on their wage residual and not their absolute wage, we avoid some of the problems inherent in defining our two independent variables of interest— the firm's compensation structure and the employee's talent level—on the wages alone. The most salient of these problems is that all high and low performers would then have extremely high or extremely low wages, thus increasing the likelihood that they would be employed by firms with high levels of wage dispersion.

Control variables. We included controls for annual earnings, annual earnings squared, age, age squared, gender, race, tenure with source firm, tenure squared, and imputed years of education in order to control for factors that may influence an individual's mobility decision. Gender and race are dummy variables which take the value of one if male and white respectively. Age, years of education, and tenure at a current employer are continuous variables. To control for individuals that do not have a strong tie to their employer, we include a dummy for individuals with less than one year of tenure at their firm. We also include a dummy that indicates if an individual's observed tenure is potentially "left-censored" because they began working at their employer before they entered the data.

\section{RESULTS}

Table 1 contains sample means and correlations. Approximately $8 \%$ of our sample change employers in any given year. Of the employees that experience a mobility event, $18 \%$ are involved in entrepreneurial founding, while the rest choose employment at existing organizations. On average, employees who change employment earn less, are younger, and have less tenure than employees that stay with their current employer. This reflects that employees who are able to appropriate high value from the current employer are less likely to be mobile, and that young workers are more mobile than more experienced workers. The demographics of the full sample and the mobility sample are very similar. The wage dispersion measure of employers is similar for employees that remain with their firm and that will leave their employer in the next period. The 
high performer and low performer indicators represent $15 \%$ and $14 \%$ of the trimmed sample respectively.

Table 2 presents the tests of our hypothesized relationships. Before turning to the models in Table 2, we note that the reference (baseline) group of employees is in the middle of the performance distribution at the MSA level (employees that are in the $20 \%-90 \%$ of the performance distribution $)^{9}$. Model 1 estimates the impact of the interaction between the employee's performance level and the firm's compensation structure on the employee's decision to leave her current firm. The relationship of the control variables to mobility of employees is consistent with the descriptive statistics and extant literature. Annual earnings, age, education and being male are negatively related with mobility, and tenure at firm has a U-shaped relationship with mobility.

Hypothesis 1 posited that the likelihood of mobility decreases for high performers who are employed at firms with higher wage dispersion. The positive and significant simple effect of high performers and negative and significant interaction effect with the firm's Gini coefficient supports this hypothesis: high performers are more likely to exit if they are employed at firms who have low Gini coefficient, and less likely to exit if they are employed at firms with higher values of Gini coefficient. Turning to the economic significance of the relationships, the coefficient values indicate that a high performer with mean characteristics employed at a firm with mean Gini coefficient has a baseline mobility rate of $3.9 \%{ }^{10}$. A one standard deviation increase in a firm's Gini coefficient decreases the probability that a high performer will exit their current employer to $3.0 \%$. This change represents a decrease of $21.8 \%$ in the mobility rate of a high performer working for a firm that is one standard deviation higher than the mean value of Gini coefficient. Similarly, because we estimate a linear probability model a one standard deviation decrease in the firm's Gini coefficient has a symmetric effect in the opposing direction. Specifically, a one standard deviation decrease in a

\footnotetext{
${ }^{9}$ We note that the main effect of the Gini coefficient of firm wage dispersion is not reported in the tables because the Gini coefficient is calculated at the firm-year level and, as a result, is absorbed by the firm-year fixed effects in the models. Given that our hypothesized relationships focus on the interactions of the Gini coefficient with high and low performing individuals, the hypothesis testing focuses on these interaction terms.

${ }^{10}$ Baseline predicted mobility rates are calculated by evaluating the fixed effect linear probability model at the means of the explanatory variables.
} 
firm's Gini coefficient increases a high performer's probability of exit to $4.7 \%$ which is an increase of $21.8 \%$.

Hypothesis 2, in contrast, posited that the likelihood of mobility increases for low performers who are employed at firms with higher wage dispersion. The coefficients for the simple and interaction effects provide support for this relationship. Low performers are more likely to exit relative to the reference group (i.e. the simple effect is positive and significant) when working for firms with low Gini coefficient values, and this likelihood is even higher for firms with higher levels of the Gini coefficient (i.e. the interaction term is positive and significant). A low performer with average characteristics at an average firm has a baseline mobility rate of $7.8 \%$. A one standard deviation increase in the employer's Gini coefficient leads to an increase in the probability that a low performer will exit their current employer to $8.1 \%$, which represents an increase of $4.1 \%$ from their baseline mobility rate. Symmetrically, a one standard deviation decrease in the employer's Gini coefficient decreases the probability of exit to $7.5 \%$, a decrease of $4.1 \%$.

The tests for hypotheses 3 and 4 are provided in Model 2 of Table 2. In this model, we examine the likelihood, conditional on mobility, of an individual engaging in entrepreneurial founding of a new firm rather than employment at an existing firm. Among the control variables, higher earners are more likely to engage in entrepreneurship than move to existing firms, as are individuals who are older, have higher education levels, and are male. Firm tenure has an inverted U-shaped relationship with the likelihood of engaging in entrepreneurship versus moving to an existing organization.

Turning to our main variables of interest, in Hypothesis 3, we predicted that the likelihood of high performers being involved in entrepreneurial founding is higher if they are employed in firms with high wage dispersion The simple effect of high performers (for firms with low values of Gini coefficient) is negative and significant, implying that high performers who are employed at firms with low wage dispersion prefer to seek employment at other existing firms, rather than engage in the creation of a new startup. In contrast, the interaction effect of high performing individuals with Gini coefficient is positive and significant which supports Hypothesis 3. High 
performing individuals working at firms with high wage dispersion are more likely to engage in entrepreneurship than high performers at firms that do not offer extreme rewards. Performing similar calculations as above for economic significance, an average high performer who leaves an average employer has a base rate of joining a start-up of $19.0 \%$. A one standard deviation increase in the pay dispersion at the employer increases the probability of joining a start-up to $21.1 \%$ which is an increase of $5.8 \%$ from the baseline rate, while a one standard deviation decrease in the pay dispersion decreases the probability of joining a start-up to $17.9 \%$, a decrease of $5.8 \%$.

Hypothesis 4 predicted a decrease in likelihood of engaging in new venture creation for low performers employed at firms with higher wage dispersion. The coefficients in Model 2 support this hypothesis. The simple effect of high performers (for firms with low values of Gini coefficient) is not significant, but the interaction term is negative and strongly significant. This implies that conditional on mobility, low performers are no more likely to form a startup when moving from firms with low levels of wage dispersion. However, they are far less likely to engage in entrepreneurship, in favor of moving to existing firms when employed at firms with higher wage dispersion. The probability of a low performer joining a start-up conditional on mobility decreases from $16.1 \%$ to $15.2 \%$ with a one standard deviation in employer pay dispersion. This represents a decrease of $5.5 \%$ from the baseline rate. Similarly, the probability of a low performer joining a startup conditional on mobility increases from $16.1 \%$ to $17.0 \%$, an increase of $5.5 \%$ after a one standard deviation decrease in employer pay dispersion.

\section{ROBUSTNESS CHECKS}

In this section, we turn to a series of robustness checks to examine the sensitivity of our hypothesis tests to alternative definitions of high and low performers, alternative measures of firms' wage dispersion, and alternative methods for trimming of our sample.

\section{Alternative definitions of high and low performers}

In the previously reported results, we defined high and low performers as those individuals in the top $10 \%$ and bottom $10 \%$, respectively, of their MSA-level wage residual distributions. If 
mobility is costless between MSAs within states, then these measures are based on an incorrect reference group and may not accurately identify the relevant group of high and low performers. To address this, we expand the reference group from the MSA level to the state level. We do not extend this logic outside of the state because state-specific bar examinations limit the ability of attorneys to practice across state lines. As demonstrated in Table 3, all hypotheses remain supported under this new definition.

\section{Alternative measures of the firm's wage distribution}

Our previously reported results rely on the Gini coefficient to capture compensation structures by measuring the dispersion in the firm's wage distribution. Following other studies (e.g. Pfeffer and Davis-Blake 1992; Shaw, Gupta and Delery, 2002) we check the robustness of our results when we measure the firm's compensation structure using alternative measures of a firm's wage dispersion. Specifically, we examine if the results are robust to using the coefficient of variation, the ratio of the $75^{\text {th }}$ and $25^{\text {th }}$ percentile, the ratio of firm Gini to the average Gini in the MSA, and the standard deviation of wage residuals. We stress however, that the Gini coefficient is, for our theoretical construct, a better measure of the firm's wage distribution because the alternative measures either do not capture the full distribution of wages in the firm, do not capture the absolute level of wage dispersion, or are more sensitive to outliers in the distribution.

First, we examine the sensitivity of results to use of the coefficient of variation to capture the compensation structure of a firm. The coefficient of variation is the standard deviation of the firm's wages divided by the mean of the firm's wages. Results from running the analysis with the coefficient of variation are reported in Table 4, Panel 1. Hypotheses 1 and 4 are still supported in this different specification. However, the coefficients for Hypotheses 2 and 3 are no longer significant. Thus, our results are partially robust to this alternative measurement of the firm's wage structure. The coefficient of variation is sensitive to outliers (Osberg, 1984) which may affect the results. 
To help resolve the conflicting results from use of the Gini and coefficient of variation, we employed a third measure of the firm's wage distribution by identifying the earnings of the individuals at the $75^{\text {th }}$ and $25^{\text {th }}$ percentile of the firm-level wage distribution and computing the ratio of these values (Donaldson and Waymark, 1980). The larger this ratio, the more disperse the distribution. The $75^{\text {th }}$ percentile $/ 25^{\text {th }}$ percentile results are presented in Table 4 , Panel 2 . We see that all four hypotheses are supported in this alternative specification. Hypothesis 4, which was strongly supported in the Gini and coefficient of variation specifications, is supported in this model at the $10 \%$ level.

It is also possible that the effect of compensation structures on the mobility decisions of employees is a relative phenomenon. That is, the level of extreme rewards offered by the firm may only be important to the extent that they differ from other firm in the employees' relevant labor market either because the employee has limited information about firms outside his labor market (Lippman and McCall, 1976), or does not want to move in order to change jobs (Topel and Ward, 1992). In order to ensure that our results are robust to this possibility of local comparisons, we divided the Gini coefficient of the focal firm by the average Gini coefficient in the employee's state. Results of this specification are presented in Table 4, Panel 3. Hypotheses 1, 2, and 4 remain supported.

Finally, our theoretical discussion relies on the idea that firms with greater pay dispersion offer more performance-based rewards than firms with less pay dispersion. Prior work indicates that pay dispersion can result from both performance-based incentives and seniority (Powell, Montgomery and Cosgrove, 1994; Shaw and Gupta, 2007). To the extent that pay dispersion results from seniority, our results may not align with our theoretical discussion. High performers being less likely to exit firms with high wage dispersion may simply be an artifact of seniority-based pay systems that reward employees for tenure, not performance. To address this concern, we measured the firm's compensation structure using the standard deviation of the firm's employees' wage 
residuals (calculated via Equation [1] $)^{11}$. This measure indicates the variation in the firm's propensity for compensating its employees based on observable demographic characteristics and tenure with the organization, a proxy for seniority. Firms that exhibit more variation in their employees' wage residuals are, to a greater extent, determining compensation based on something other than demographics and tenure, and we suggest that this unobservable characteristic is likely to be performance. Results of analysis using this measure are presented in Table 4, Panel 4. In this robustness check, all hypotheses are supported.

In sum, we test our hypotheses by using 5 different ways of measuring wage dispersion. Hypotheses 1 and 4 are supported across all five measures of compensation structure, and the remaining two hypotheses are supported in the majority of cases.

\section{Redefining the sample}

We examine the sensitivity of the results to alternative samples of the data. First, we focus only on observations within the boundaries of a Metropolitan Statistical Area, we then focus only on observations with at least 16 years of education. In the baseline analysis we compared the wage residuals of employees to other members of the legal services industry inside of their MSA. In order to include non-MSA employees in our sample, we identified high and low performing employees not employed in an MSA by comparing their wage residual to the weighted average of the cutoff for high and low performers within the MSAs in the state. To ensure that our results were robust to this methodology, we performed our baseline analysis only on workers employed in an MSA. The results (not reported due to disclosure considerations) supported each of the hypotheses.

In order to ensure that our results for low performers are not being driven by employees with lower human capital such as secretaries and paralegals, we repeated the analysis while restricting the sample to only those individuals with at least 16 years of education. Again, the (unreported) results supported each of the hypotheses.

\footnotetext{
${ }^{11}$ We use standard deviation of wage residuals instead of the Gini coefficient or the coefficient of variation because approximately half of the wage residuals have negative values and computation of a Gini coefficient or coefficient of variation using these values is not feasible (Chen, Tsaur and Rai, 1982).
} 


\section{DISCUSSION AND CONCLUSION}

Our study is aimed at understanding how an important macro-level strategic firm decisioncompensation structure-interacts with micro-level differences in employee performance to explain individual decisions to stay with a current employer, move to an existing firm, or engage in entrepreneurial creation of a new firm. The question we examine is at the heart of issues related to strategic human capital, and integrates across literature streams of human resource management, labor economics, strategy and entrepreneurship to contribute new insights regarding employee mobility and entrepreneurship.

We find that individuals who exhibit high performance relative to their peers within their metropolitan statistical area are less likely to leave firms with more dispersed compensation structures (Hypothesis 1). However, if a high performer decides to exit, she is more likely to form a startup than to join an established competitor as the presence of extreme rewards at her former firm increases (Hypothesis 3). As expected, our results are different for less talented employees. These individuals are more likely to exit firms with more dispersed compensation structures (Hypothesis 2). In contrast to the results for high performers, as the pay dispersion of his former employer increases, a low performer is less likely to start his own firm, probably because there are other options in the labor market that do not link pay so tightly to performance (Hypothesis 4).

The pattern of results for high performers suggests that talented employees are motivated by and seek out the strongest incentives available and will create these incentives via entrepreneurship if they cannot access them in the existing labor market. These incentives can include both monetary rewards of employment with an established firm that rewards extreme performance and the pecuniary and nonpecuniary benefits of entrepreneurship. The results for low performers, on the other hand, suggest that low performers avoid contexts that focus on performance contingent rewards including established firms that offer extreme rewards and start-ups. A low performer is not likely to benefit from the extreme rewards at a firm with a disperse compensation structure and is also likely to suffer the psychological costs associated with envy and comparison to higher performing colleagues. Instead of seeking contexts with extreme rewards, low performers are likely 
to seek employment where such comparisons are less stark and where high performers implicitly subsidize the compensation of low performers.

The result that high performers are less likely to leave firms with more dispersed compensation structures raises a puzzling question. If more dispersed firms are more likely to retain high performing employees, why don't all legal services firms adopt dispersed wage structures? One explanation is that firms may choose flatter wage structures to encourage cooperation and reduce envy (Lazear, 1989; Nickerson and Zenger, 2008) especially when employees are engaged in interdependent tasks (Shaw, Gupta and Delery, 2002; Bloom, 1999). In addition, wage structures may become institutionalized over time (Doeringer and Piore, 1971).

Our data seem to agree with this latter suggestion. The correlation between a firm's Gini coefficient at time $t$ and at time $(t-1)$ is .86. In addition, we ran supplemental regressions (not reported) of the Granger causality relationship between the firm's Gini coefficient and the number of high performers it lost in one, two, three, and four year windows. We then did the same analysis replacing the number of lost high performers with the number of lost low performers. Results indicate that the firm's Gini coefficient "Granger causes" the departure of high and low performing employees, not the other way around.

\section{Limitations and Future Research}

This study has several limitations which open up additional avenues for future research. The first is the generalizability of the context. Although the empirical literature (Malos and Campion, 1995; Parkin and Baker, 2006) has shown that legal services firms are not exclusively tournamentbased organizations, it is probable that our setting contains more of these types of firms than other industries. In addition, the mechanisms for employee entrepreneurship are likely to be different in professional services than manufacturing firms (Teece, 2003) due to the lower overhead and relative ease of taking complementary human assets from parents to spin-outs (Campbell, et al. 2010). Most importantly, legal services firms (or any partnership) are different from publicly traded corporations in that the same individuals who have residual claimancy also have residual rights of control. Thus, in a legal services firm, the same people who will be benefiting from the firm's compensation 
structure also choose that compensation structure. This is different from a public company where at least one independent director must be on the compensation committee. As a result of these limiting factors, further research is necessary to see if our results apply in other empirical settings.

Additionally, data limitations prevent us from differentiating between vertical and horizontal pay dispersion because we cannot discern the job groups of the employees in our sample. While the firm can implement differential rewards using either type of pay dispersion (Gerhart and Rynes, 2003), an interesting question for future work is whether the exit decisions of extreme performers are more strongly influenced by vertical or horizontal pay variance and also whether the decision to join an entrepreneurial firm is influenced by the different types of pay dispersion..

Relying on prior literature, we assumed that entrepreneurship offers skilled employees higher rewards than working for an established firm (Gort and Lee, 2007; Braguinsky and Ohyama, 2009). An interesting topic for future research is to examine the type of wage distribution implemented by startup firms to further refine the understanding of the relationship between start-up rewards and established firm rewards. For example, do startups create compensation structures that are radically different from their parent firms? How does the presence of a high performer affect the compensation structure of a start-up? Answering these questions would further illuminate employees' motivations for starting new firms.

In a similar vein, another topic for future research is the persistence of extreme individual performance and firms' compensation structures after different types of mobility. Do high performers remain high performers after joining a start-up? Do low-performers? Are average performers more likely to become high performers at a start-up or at an established firm? Under what conditions does employee mobility affect firm wage structure? Further research on these questions would add to the understanding on the interaction between individual characteristics and decisions and firm characteristics and strategies. 


\section{Contributions}

This paper makes a number of contributions to the fields of research that are concerned with the strategic management of human capital. To scholars interested the strategic management of knowledge, our evidence suggests that the compensation structure of the firm has important consequences for the diffusion and transfer of knowledge to competing organizations and that the firm's human resource management and knowledge management practices are inextricably linked (Coff, 1997). To the extent that skilled employees possess a disproportionate amount of the firm's knowledge (Zucker, et al 2002), providing access to extreme rewards will help limit the mobility of these individuals and keep their knowledge inside the boundaries of the firm. However, providing extreme rewards is not a panacea for minimizing the potentially adverse effects of knowledge leakage from employee exit. High performers are more likely to create their own firms when leaving parents that provide extreme rewards, and the creation of these startups--doppelgangers where the parents' best former employees utilize knowledge (Agarwal, et al. 2004), routines (Wezel, Cattani and Pennings, 2006) and complementary assets (Campbell, et al. 2010) transferred from the parent organization--are worse for parent firm performance than the exit of a high performer to an established competitor (Campbell, et al. 2010; Phillips, 2002; Wezel, et al. 2006).

Extant literature that considers the employee as an important conduit of knowledge has generally examined employee mobility and employee entrepreneurship in isolation. We contribute to the growing literature that focuses on the interrelation of these two phenomena (Campbell, et al. 2010; Phillips, 2002, Groysberg, et al. 2009) by suggesting that the availability of extreme rewards inside of the parent organization is a key contingency driving the employee's decision to either move to an established competitor or form a new firm. Our insight that that the firm's compensation structure will impact the exit decisions of employees differently depending on their level of performance is particularly important because it helps unpack the reason why high performers are more likely to be the founders of startup firms - they may have already maximized the performance contingent rewards available in the existing labor market. 
We contribute to the HR literature on voluntary turnover by pointing out that not all mobility events are created equal — the ultimate destination of the departing employee is important to consider when studying how firms can control turnover. In the current turnover literature, the distinction between mobility to established firms and mobility to new firms is often confounded, but the motives and competitive outcomes from these two types of mobility may vary considerably (Klepper and Thompson, 2010; Campbell et al. 2010). As a result, firms need to consider that they are competing with both new firms and established competitors for the services of high-performing employees and design their human resource practices accordingly. Specifically, our results suggest that firms may need to complement compensation structures that provide for extreme rewards with other HRM practices that will encourage the retention of potential entrepreneurs.

We make several contributions to the strategic entrepreneurship literature. A significant body of literature examines how individual characteristics are correlated with the decision to become an entrepreneur (Lazear, 2005; Nicolau et al., 2008; Robinson \& Sexton, 1994; Campbell et al, 2010). A parallel stream focuses on how firm-level strategies regarding technology and knowledge configuration (Agarwal, et al, 2004; Franco and Filson, 2006) affect the entrepreneurial decision. In combination, these studies suggest that good parents make good progeny (Agarwal et. al, 2004) partly because good employees are more likely to be the progenitors (Groysberg, et al. 2009; Campbell, et al. 2010). We integrate across literatures by showing how strategic decisions made by the parent firm will not uniformly affect the entrepreneurship decisions of employees because employees will vary in their aspiration and ability to create new ventures. Namely, this paper suggests that the compensation structure of the parent firm is important to consider and that future work should consider both human resource and knowledge management practices when examining the creation of spin-outs.

Relatedly, we also provide some preliminary linkages across the literatures that examine employee capabilities (Campbell, et al. 2010; Groysberg et al, 2009; Phillips 2002) and the pecuniary and nonpecuniary incentives of entrepreneurship (Hamilton, 2000). Our results suggest that firms can structure compensation in order to retain high performers. However, they also indicate that 
sometimes the wage policies of the firm cannot compete with the potential rewards of entrepreneurship for these high performing employees. A high performing employee in a firm that provides extreme rewards likely already has the opportunity to earn pecuniary compensation that is closely commensurate with the value of her talents. The result that high performing employees who leave firms with more dispersed compensation structures are more likely to found new ventures suggests that these individuals may not be satisfied with the nonpecuniary returns to their ability. Consequently, our results suggest that a firm's highest performers - its employees who are most capable of transferring the routines and complementary assets necessary to form a new venturemay also have the strongest nonpecuniary incentive to enter entrepreneurship.

In summary, by examining the decisions of extreme performers and firms that offer extreme rewards, we find that high performers are less likely to leave firms that offer extreme rewards, but if they do leave firms that offer extreme rewards, they are more likely to engage in entrepreneurial new venture creation. We also find that low performers are more likely to leave firms that offer extreme rewards and are less likely to leave firms that offer extreme rewards for employee entrepreneurship. Our findings suggest that individuals choose the compensation structure that is the best fit for their expectations of pecuniary and nonpecuniary rewards and that firms can influence the mobility behavior of their employees through their choice of compensation structure. As a result, our study illuminates the interrelationship of individual decisions and firm-level strategic decisions. This interrelationship has been understudied by scholars of employee mobility and employee entrepreneurship. This paper hopes to stimulate further discussion on how individuals' decisions and firm strategies operate in concert and how the decisions of employees affect the strategies of the firm at the same time that the strategies of the firm affect the decisions of employees. 


\section{REFERENCES}

Adams, J. S. 1963. Journal of Abnormal and Social Psychology, 67(5): 422-436.

Agarwal, R., Campbell, B., Franco, A., \& Ganco, M. 2010. What do I take with me? the impact of transfer and replication of resources on performance. Working paper, The University of Illinois.

Agarwal, R., Echambadi, R., Franco, A. M., \& Sarkar, M. B. 2004. Knowledge transfer through inheritance: Spin-out generation, development, and survival. Academy of Management Journal, 47(4): 501-522.

Anton, J. J., \& Yao, D. A. 1995. Start-ups, spin-offs, and internal projects. Journal of Law, Economics \& Organization, 11(2): 362.

Audretsch, D. B., \& Stephan, P. E. 1996. Company-scientist locational links: The case of biotechnology. American Economic Review, 86(3): 641-652.

Becker, G. S. 1962. Investment in human capital: A theoretical analysis. The Journal of Political Economy, 70(5, Part 2: Investment in Human Beings): 9-49.

Berkowitz, L., Fraser, C., Treasure, F. P., \& Cochran, S. 1987. Pay, equity, job gratifications, and comparisons in pay satisfaction. Journal of Applied Psychology, 72(4): 544-551.

Blanchflower, D. G., \& Oswald, A. J. 1998. What makes an entrepreneur? Journal of Labor Economics, 16(1): 26.

Bloom, M. 1999. The performance effects of pay dispersion on individuals and organizations. Academy of Management Journal, 42(1): 25-40.

Bloom, M., \& Michel, J. G. 2002. The relationships among organizational context, pay dispersion, and among managerial turnover. Academy of Management Journal, 45(1): 33-42.

Blyler, M., \& Coff, R. W. 2003. Dynamic capabilities, social capital, and rent appropriation: Ties that split pies. Strategic Management Journal, 24(7): 677.

Boden Jr., R. J. 1996. Gender and self-employment selection: An empirical assessment. Journal of Socio-economics, 25(6): 671.

Braguinsky, S., \& Ohyama, A. 2009. Where does entrepreneurship pay? Working paper, Carnegie Mellon University.

Burton, MD, Sørensen, JB, \& Beckman, C. 2002. Coming from good stock: Career histories and new venture formation. In Research in the sociology of organizations, vol. 19: 229-262. 
Campbell, B. 2010. Does start-up experience pay? evidence from the semiconductor industry. Working paper, The Ohio State University.

Campbell, B., Ganco, M., Franco, A., \& Agarwal, R. 2010. Who leaves, where to, and why worry?: Employee mobility, employee entrepreneurship, and effects on source firm performance. Working paper, The Ohio State University.

Chatman, J. A. 1989. Improving interactional organizational research: A model of personorganization fit. Academy of Management Review, 14(3): 333-349.

Chen, C., Tsaur, T., \& Rhai, T. 1982. The gini coefficient and negative income. Oxford Economic Papers, 34(3): 473-478.

Coff, R. W. 1997. Human assets and management dilemmas: Coping with hazards on the road to resource-based theory. The Academy of Management Review, 22(2): 374.

Coff, R. W. 1999. When competitive advantage doesn't lead to performance: The resource-based view and stakeholder bargaining power. Organization Science, 10(2): 119-133.

Doeringer, P. B., Piore, M. J., \& United States. Dept. of Labor. Manpower Administration. 1971. Internal labor markets and manpower analysis. Lexington, Mass.: Heath.

Donaldson, D., \& Weymark, J. A. 1980. A single-parameter generalization of the gini indices of inequality. Journal of Economic Theory, 22(1): 67-86.

Dwyer, D. J., \& Ganster, D. C. 1991. The effects of job demands and control on employee attendance and satisfaction. Journal of Organizational Behavior, 12(7): 595-608.

Elfenbein, D., Hamilton, B., \& Zenger, T. 2009. The small firm effect and the entrepreneurial spawning of scientists and engineers. Working paper.

Ernst, H., \& Vitt, J. 2000. The influence of corporate acquisitions on the behavior of key inventors. R\&D Management, 30(2): 105.

Festinger, L. 1954. A theory of social comparison processes. Human Relations, 7: 117-140.

Franco, A. M., \& Filson, D. 2006. Spin-outs: Knowledge diffusion through employee mobility. RAND Journal of Economics, 37(4): 841-860.

Frank, R. H. 1984. Are workers paid their marginal products? American Economic Review, 74(4): 549.

Ganco, M. 2009. The influence of technological interdependence on employee entrepreneurship and mobility: Evidence from the semiconductor industry. Working paper.

Gerhart, B. A., \& Rynes, S. 2003. Compensation : Theory, evidence, and strategic implications. Thousand Oaks, CA: Sage. 
Gompers, P., Lerner, J., \& Scharfstein, D. 2005. Entrepreneurial spawning: Public corporations and the genesis of new ventures, 1986 to 1999. Journal of Finance, 60(2): 577-614.

Gort, M., \& Lee, S. 2007. The rewards to entrepreneurship. Working paper, SUNY Buffalo.

Griffeth, R. W., Hom, P. W., \& Gaertner, S. 2000. A meta-analysis of antecedents and correlates of employee turnover: Update, moderator tests, and research implications for the next millennium. Journal of Management, 26(3): 463-488.

Groysberg, B., Nanda, A., \& Prats, M. 2009. Does individual performance affect entrepreneurial mobility? empirical evidence from the financial analysts market. Journal of Financial Transformation, 25(March): 95-106.

Hamilton, B. H. 2000. Does entrepreneurship pay? an empirical analysis of the returns to selfemployment. Journal of Political Economy, 108(3): 604.

Harrison, D. A., Virick, M., \& William, S. 1996. Working without a net: Time, performance, and turnover under maximally contingent rewards. Journal of Applied Psychology, 81(4): 331-345.

Holmstrom, B., \& Milgrom, P. 1991. Multitask principal--agent analyses: Incentive contracts, asset ownership, and job design. Journal of Law, Economics \& Organization, 7(2): 24.

Klepper, S., \& Thompson, P. 2010. Spinoff entry in high-tech industries: Motives and consequences. International Journal of Industrial Economics, Forthcoming.

Klepper, S., \& Sleeper, S. 2005. Entry by spinoffs. Management Science, 51(8): 1291-1306.

Krackhardt, D., \& Porter, L. W. 1986. The snowball effect: Turnover embedded in communication networks. Journal of Applied Psychology, 71(1): 50-55.

Lambert, R. A., Larcker, D. F., \& Weigelt, K. 1993. The structure of organizational incentives. Administrative Science Quarterly, 38(3): 438-461.

Lazear, E. P. 1989. Pay equality and industrial politics. Journal of Political Economy, 97(3): 561.

Lazear, E. P. 1999. Personnel economics: Past lessons and future directions. Journal of Labor Economics, 17(2): 199.

Lazear, E. P. 2005. Entrepreneurship. Journal of Labor Economics, 23(4): 649-680.

Lazear, E. P., \& Rosen, S. 1981. Rank--order tournaments as optimum labor contracts. Journal of Political Economy, 89(5): 841.

Lewicki, P. 1983. Self-image bias in person perception. Journal of personality and social psychology, 45(2): 384-393. 
Lippman, S. A., \& McCall, J. J. 1976. The economics of job search: A survey. Economic inquiry, 14(2): 155.

Malos, S. B., \& Campion, M. A. 1995. An options-based model of career mobility in professional service firms. Academy of Management Review, 20(3): 611-644.

Marsh, R. M., \& Mannari, H. 1977. Organizational commitment and turnover: A prediction study. Administrative Science Quarterly, 22(1): 57-75.

Milgrom, P. R., \& Roberts, J. 1992. Economics, organization, and management. Englewood Cliffs, N.J.: Prentice-Hall.

Mindruta, D. 2008. Value creation in university-firm research collaborations: A matching approach. Academy of Management Proceedings: 1-6.

Miyazaki, H. 1977. The rat race and internal labor markets. The Bell Journal of Economics, 8(2): 394-418.

Nickerson, J. A., \& Zenger, T. R. 2008. Envy, comparison costs, and the economic theory of the firm. Strategic Management Journal, 29(13): 1429-1449.

Nicolaou, N., Shane, S., Cherkas, L., Hunkin, J., \& Spector, T. D. 2008. Is the tendency to engage in entrepreneurship genetic? Management Science, 54(1): 167-179.

Osberg, L. 1984. Economic inequality in the united states. Armonk, N.Y.: M.E. Sharpe.

Parker, S. C. 2009. Why do small firms produce the entrepreneurs? Journal of Socio-economics, 38(3): 484-494.

Parkin, R., \& Baker, G. 2006. The changing structure of the legal services industry and the careers of lawyers. North Carolina Law Review, 84: 1635-1682.

Parkin, R. 2007. Linking career paths, firm organization, and industry structure in legal services (Ph.D. ed.). United States -- Massachusetts: Harvard University.

Parsons, D. O. 1977. Models of labor market turnover: A theoretical and empirical survey. In R. Ehrenberg (Ed.), Research in labor economics: 185-223. Greenwich, CT: JAI Press.

Pfeffer, J., \& Davis-Blake, A. 1992. Salary dispersion, location in the salary distribution, and turnover among college administrators. Industrial \& labor relations review, 45(4): 753-763.

Phillips, D. J. 2002. A genealogical approach to organizational life chances: The parent-progeny transfer among silicon valley law firms, 1946-1996. Administrative Science Quarterly, 47(3): 474506.

Powell, I., Montgomery, M., \& Cosgrove, J. 1994. Compensation structure and establishment quit and fire rates. Industrial Relations, 33(2): 229-248. 
Puri, M., \& Robinson, D. T. 2007. Optimism and economic choice. Journal of Financial Economics, 86(1): 71-99.

Rasmusen, E., \& Zenger, T. 1990. Diseconomies of scale in employment contracts. Journal of Law, Economics \& Organization, 6(1): 65.

Robinson, P. B., \& Sexton, E. A. 1994. The effect of education and experience on self-employment success. Journal of Business Venturing, 9(2): 141.

Shane, S., \& Cable, D. 2002. Network ties, reputation, and the financing of new ventures.

Management Science, 48(3): 364-381.

Shaw, J. D., \& Gupta, N. 2007. Pay system characteristics and quit patterns of good, average, and poor performers. Personnel Psychology, 60(4): 903-928.

Shaw, J. D., Gupta, N., \& Delery, J. E. 2002. Pay dispersion and workforce performance:

Moderating effects of incentives and interdependence. Strategic Management Journal, 23(6): 491.

Sørensen, J. B. 2007. Bureaucracy and entrepreneurship: Workplace effects on entrepreneurial entry. Administrative Science Quarterly, 52(3): 387-412.

Sorenson, O., \& Stuart, T. E. 2001. Syndication networks and the spatial distribution of venture capital investments. American Journal of Sociology, 106(6): 1546-1588.

Stumpf, S. A., \& Dawley, P. K. 1981. Predicting voluntary and involuntary turnover using absenteeism and performance indices. Academy of Management Journal, 24(1): 148-163.

Teece, D. J. 1986. Profiting from technological innovation: Implications for integration, collaboration, licensing and public policy. Research Policy, 15(6): 285.

Teece, D. J. 2003. Expert talent and the design of (professional services) firms. Industrial $\boldsymbol{\&}$ Corporate Change, 12(4): 895-916.

Topel, R. H., \& Ward, M. P. 1992. Job mobility and the careers of young men. Quarterly Journal of Economics, 107(2): 439.

Weiss, A. 1990. Efficiency wages : Models of unemployment, layoffs, and wage dispersion. Princeton, N.J.: Princeton University Press.

Williams, C. R., \& Livingstone, L. P. 1994. Another look at the relationship between performance and voluntary turnover. Academy of Management Journal, 37(2): 269-298.

Wills, J. S. 1991. Social comparison processes in envy and jealousy. In Social comparison: Contemporary theory and research: 261-285. Hillsdale, New Jersey: Lawrence Erlbaum Associates. 
Zenger, T. R. 1992. Why do employers only reward extreme performance? examining the relationships among performance, pay, and turnover. Administrative Science Quarterly, 37(2): 198-219.

Zucker, L. G., Darby, M. R., \& Armstrong, J. S. 2002. Commercializing knowledge: University science, knowledge capture, and firm performance in biotechnology. Management Science, 48(1): 138-153.

Zucker, L. G., Darby, M. R., \& Brewer, M. B. 1998. Intellectual human capital and the birth of U.S. biotechnology enterprises. American Economic Review, 88(1): 290-306. 
Table 1

Sample Means and Correlations

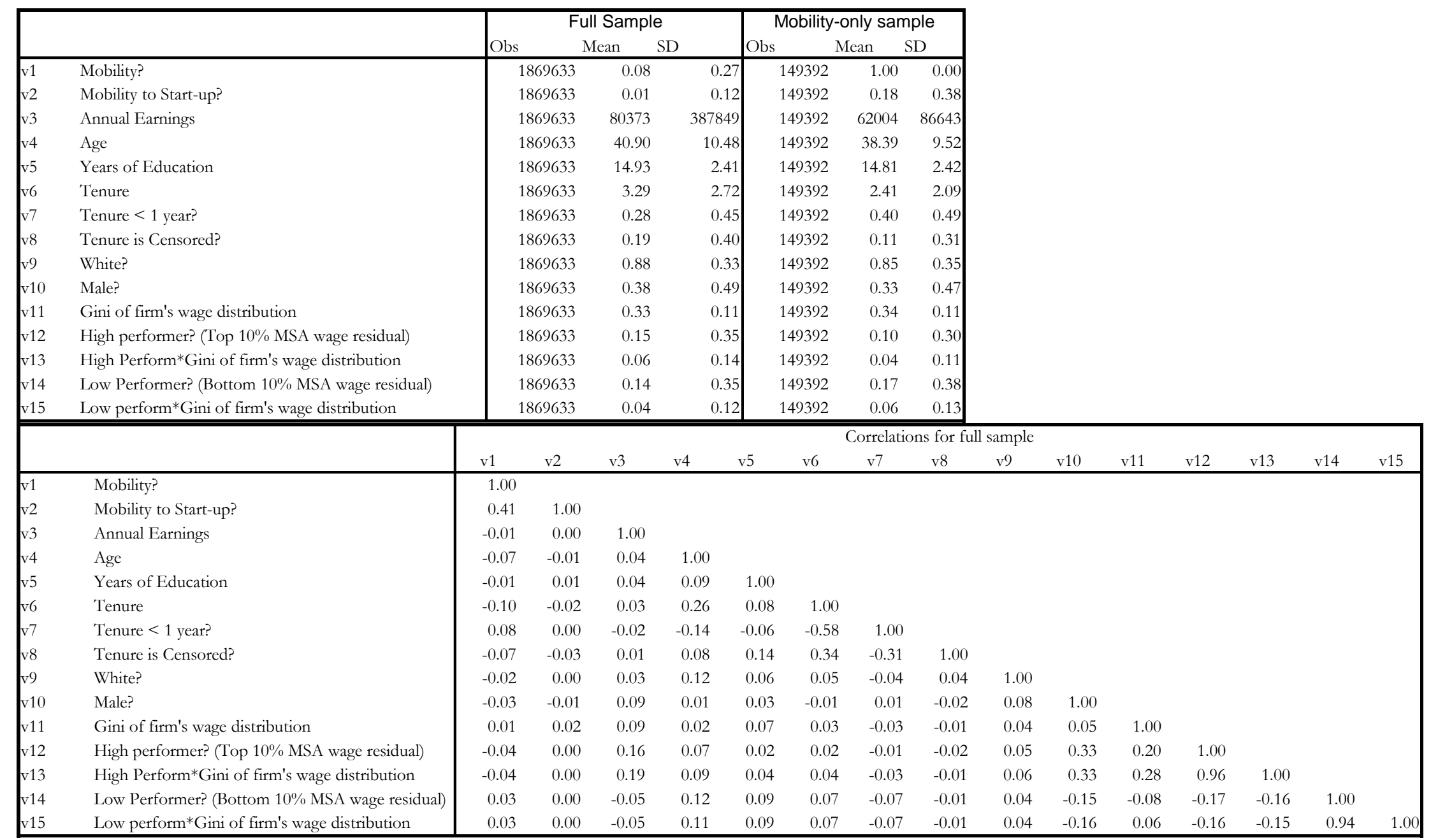


Table 2

Models of Employee Mobility and Employee Entrepreneurship for MSA-level High and Low Performers

\begin{tabular}{|c|c|c|c|c|}
\hline & \multicolumn{2}{|c|}{$\begin{array}{c}\text { Model } 1 \\
\text { DV: Mobility }\end{array}$} & \multicolumn{2}{|c|}{$\begin{array}{c}\text { Model } 2 \\
\text { DV: Mobility to Spin-out } \mid \\
\text { Mobility }\end{array}$} \\
\hline Is the employee a high performer? (Top 10\% MSA wage residual) & $0.0122 * * *$ & $(0.0031)$ & $-0.0275 *$ & $(0.0145)$ \\
\hline Is the employee a low performer? (Bottom 10\% MSA wage residual) & $0.0125 * * *$ & $(0.0022)$ & 0.0093 & $(0.0086)$ \\
\hline High Performer*Gini of firm's wage dist & $-0.0849 * * *$ & $(0.0075)$ & $0.1097 * * *$ & $(0.0414)$ \\
\hline Low Performer*Gini of firm's wage dist & $0.0315 * * *$ & $(0.0066)$ & $-0.0889 * * *$ & $(0.0255)$ \\
\hline Age & $-0.0010 * * *$ & $(0.0001)$ & $0.0017 * *$ & $(0.0007)$ \\
\hline $\operatorname{Age}^{\wedge} 2(x 100)$ & -0.0002 & $(0.0001)$ & $-0.0014 *$ & $(0.0008)$ \\
\hline Years of Education (Imputed) & $-0.0004 * * *$ & $(0.0001)$ & $0.0015 * * *$ & $(0.0004)$ \\
\hline Years of Tenure & $-0.0206 * * *$ & $(0.0005)$ & $0.0169 * * *$ & $(0.0020)$ \\
\hline Years of Tenure^2 & $0.0013 * * *$ & $(0.0000)$ & $-0.0010 * * *$ & $(0.0002)$ \\
\hline Tenure $<1$ year? & 0.0003 & $(0.0013)$ & 0.0047 & $(0.0037)$ \\
\hline Tenure is Censored? & $-0.0127 * * *$ & $(0.0011)$ & 0.0062 & $(0.0054)$ \\
\hline Male & $-0.0049 * * *$ & $(0.0007)$ & $0.0103 * * *$ & $(0.0022)$ \\
\hline Annual Earnings $(x 100,000)$ & $-0.0006 * * *$ & $(0.0001)$ & $0.0163 * * *$ & $(0.0036)$ \\
\hline Annual Earnings^2 (x100,000^2) & 0.00001 & $(0.0003)$ & $-0.0163 * * *$ & $(0.0055)$ \\
\hline Constant & 0.1639 & $(124.5679)$ & $0.0618 * * *$ & $(0.0144)$ \\
\hline $\begin{array}{r}\text { N Observations } \\
\text { N Groups } \\
\mathrm{R}^{\wedge} 2\end{array}$ & \multicolumn{2}{|l|}{$\begin{array}{r}1869633 \\
87273 \\
0.0160\end{array}$} & \multicolumn{2}{|l|}{$\begin{array}{r}149392 \\
41306 \\
0.0278\end{array}$} \\
\hline
\end{tabular}

Note: Models control for race and include firm-year fixed effects.

Models use robust standard errors (clustered by firm-year)

*** Significant at the $1 \%$ level

** Significant at the 5\% level

* Significant at the $10 \%$ level 
Table 3

Robustness Check: Models of Employee Mobility and Employee Entrepreneurship for State-level High and Low Performers

\begin{tabular}{|c|c|c|c|c|}
\hline & \multicolumn{2}{|c|}{$\begin{array}{c}\text { Model } 1 \\
\text { DV: Mobility }\end{array}$} & \multicolumn{2}{|c|}{$\begin{array}{c}\text { Model } 2 \\
\text { DV: Mobility to Spin-out } \\
\text { Mobility } \\
\end{array}$} \\
\hline Is the employee a high performer? (Top 10\% State wage residual) & -0.0043 & $(0.0032)$ & -0.0076 & $(0.0170)$ \\
\hline Is the employee a low performer? (Bottom 10\% State wage residual) & $0.0167 * * *$ & $(0.0021)$ & -0.0048 & $(0.0091)$ \\
\hline High Performer*Gini of firm's wage dist & $-0.0588 * * *$ & $(0.0074)$ & $0.1039 * *$ & $(0.0466)$ \\
\hline Low Performer*Gini of firm's wage dist & $0.0332 * * *$ & $(0.0063)$ & $-0.0672 * * *$ & $(0.0257)$ \\
\hline Age & $-0.0010 * * *$ & $(0.0001)$ & $0.0017 * *$ & $(0.0007)$ \\
\hline $\operatorname{Age}^{\wedge} 2(x 100)$ & $-0.0025 *$ & $(0.0014)$ & $-0.0134 *$ & $(0.0078)$ \\
\hline Years of Education (Imputed) & $-0.0004 * * *$ & $(0.0001)$ & $0.0018 * * *$ & $(0.0004)$ \\
\hline Years of Tenure & $-0.0205 * * *$ & $(0.0005)$ & $0.0170 * * *$ & $(0.0020)$ \\
\hline Years of Tenure^2 & $0.0013 * * *$ & $(0.0000)$ & $-0.0010 * * *$ & $(0.0002)$ \\
\hline Tenure $<1$ year? & 0.0002 & $(0.0013)$ & 0.0047 & $(0.0037)$ \\
\hline Tenure is Censored? & $-0.0126 * * *$ & $(0.0011)$ & 0.0060 & $(0.0054)$ \\
\hline Male & $-0.0055 * * *$ & $(0.0005)$ & $0.0090 * * *$ & $(0.0021)$ \\
\hline Annual Earnings $(x 100,000)$ & $-0.0037 * * *$ & $(0.0012)$ & $0.1130 * * *$ & $(0.0313)$ \\
\hline Annual Earnings`2 (x100,000^2) & $0.00001 * * *$ & $(0.000003)$ & $-0.0117 * * *$ & $(0.0043)$ \\
\hline Constant & 0.1619 & $(137.7376)$ & $0.0589 * * *$ & $(0.0144)$ \\
\hline $\begin{array}{r}\text { N Observations } \\
\text { N Groups } \\
\mathrm{R}^{\wedge} 2\end{array}$ & \multicolumn{2}{|l|}{$\begin{array}{r}1869633 \\
87273 \\
0.0164 \\
\end{array}$} & \multicolumn{2}{|l|}{$\begin{array}{r}149392 \\
41306 \\
0.0283 \\
\end{array}$} \\
\hline
\end{tabular}

Note: Models control for race and include firm-year fixed effects.

Models use robust standard errors (clustered by firm-year)

*** Significant at the $1 \%$ level

** Significant at the $5 \%$ level

* Significant at the $10 \%$ level 
Table 4

Robustness Checks: Alternative Measures of the Firm's Wage Structure

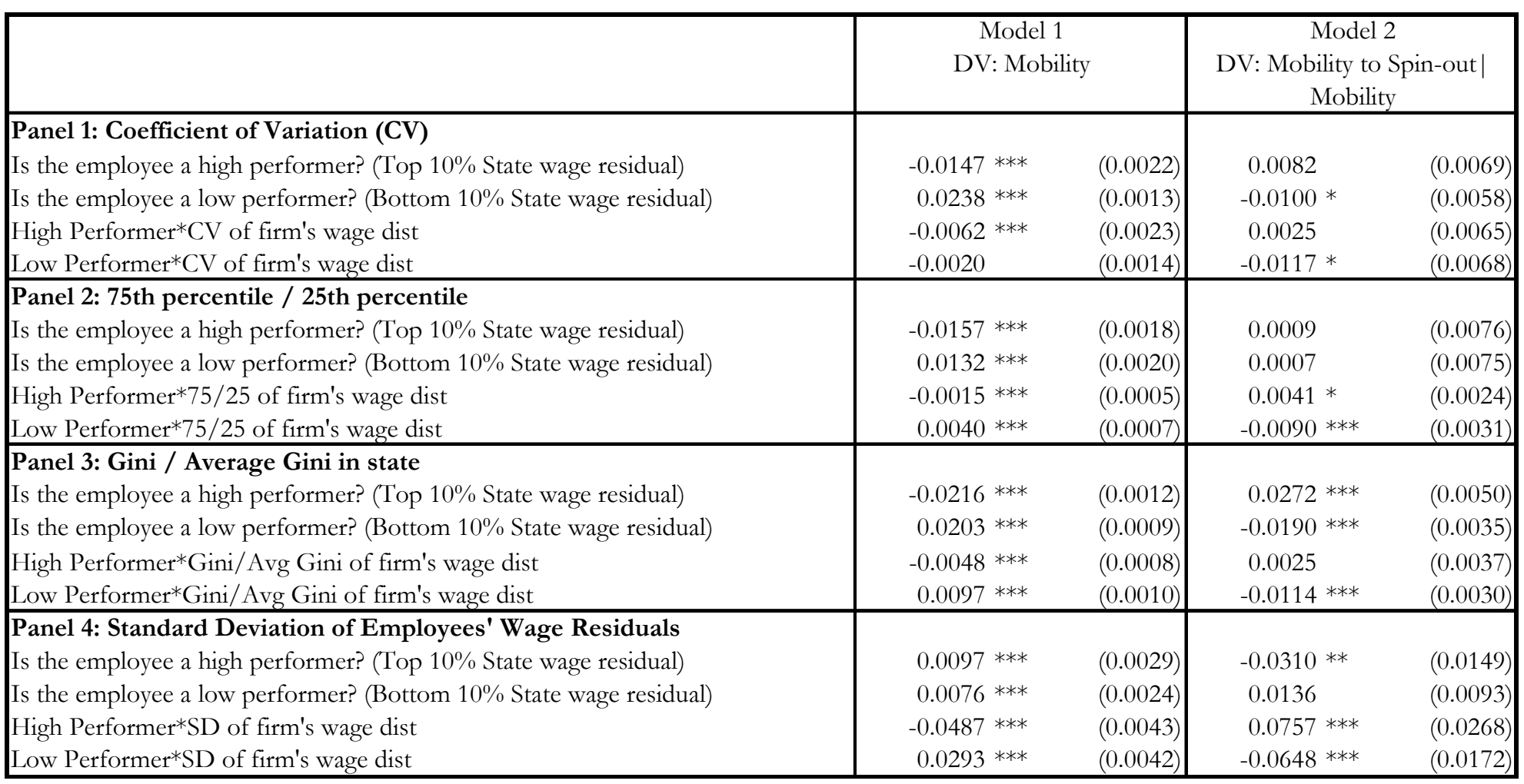

Note: Models control for the same independent variables as in Tables 2 and 3, including race and firm-year fixed effects.

Models use robust standard errors (clustered by firm-year)

$* * *$ Significant at the $1 \%$ level

$* *$ Significant at the $5 \%$ level

* Significant at the $10 \%$ level 